lightened them. Virtue's reward, moreover, has always satisfied a greed not merely for certain goods, but also for still larger possibilities. Whoever wins, be he gambler or gallant, wins the chance of winning more.

This essay on the possibilities of gallant living may very properly close with the simple remark that ability to take chances is a power possessed by every individual. Also, as in the case of any other power of individuals, it may be spoken of as one of any nation's important resources. Nations have so-called physical resources, that is, water-power, coal mines, climate, soil, strategic positions and the like, but they have also resources of a less tangible yet surely not less important sort in the peculiar character of their people or in the more general characters of all human beings and of these subtler resources the ability to take chances, is, I would assert with great emphasis, of inestimable value. Carefully protect and develop this power by proper training in the home and by a public education at school or in the civil and political and industrial life or in the church that will induce habits of care and orderliness and a disposition to honest thought and effort and to independence in both of these, and the nation will grow and grow strong, for its dice will be honestly loaded. Waste this great power with gambling, I do not mean the so-called professional gambling, for that is only local and relatively insignificant, but the gambling which is manifest in the circulating life-blood of the people at large, in the shiftlessness and the shoddyism, in the "get rich quick" schemes of all sorts and the high finance and in all the other profane uses of a life of chance, and the waste, whatever be the apparent winnings, will end in weakness and disaster. The modern nation is indeed rich, rich in the power of taking chances, but out of the wastefulness that has gone on for so long and that is so widespread there comes a call that must not go unheeded, for men who, instead of gambling, will play fairly and live gallantly.

UNIVERSITY OF MichigAN.

AlfRed H. Lloyd.

\title{
WORK TO BE DONE IN BUDDHIST CRITICISM.
}

AN APPEAL TO CHINESE SCHOLARS. ${ }^{1}$

Perhaps there is nothing more romantic in the history of religion than the spectacle of a Parthian prince renouncing his throne in A. D.

${ }^{1}$ This communication was inserted by mistake without correction in the January number of The Monist (pp. 158-160) and is here reproduced in its proper form. 
I 49 and going to China as a Buddhist monk. This remarkable man, An-shi-kao by name, spent his life in his adopted country, rendering parts of the sacred writings into Chinese. According to Nanjio's Catalogue of the Chinese Tripitaka (Oxford, 1883 ), the prince translated $\mathrm{I} 76$ original works, of which 55 are extant. Judging from their titles, 43 of these are Hinayana. Anesaki, in his priceless essay, "The Four Buddhist Agamas in Chinese" (Transactions of the A siatic Society of Japan, Tokyo, 1908, pp. 17, 18; 28-31) identifies forty-four of these works with texts now extant in the Pali canon.

Let us look at some of these texts, and see what kind of books were valued in Parthia and China at the time of Justin Martyr! Going through the Pali Nikayas in regular order, the first that we find is the Mahanidana-sutta (Digha No. 15). This was considered important enough to be included in Grimblot's selections from the Long Collection (Paris, 1876 ) and in Warren's Buddhism in Translations (Cambridge, Massachusetts, 1896 ). The next is No. $3^{1}$ in the same Nikaya, also published by Grimblot, and finally there is the last sutta therein, No. 34, the Dasuttara, which gives a remarkable survey of Buddhist doctrine, under categories numbered from one to ten.

In the great Middling Collection (as I prefer to call it, because it is named after the medium length of its sutras, and not after its position in the Agamas, which varied) our Parthian prince hit upon No. 6, which Rhys Davids chose in London, I700 years later, for translation into English in Sacred Books of the East, Vol. XI. Next we come to No. $5^{2}$, and then to No. 87 , then to No. II3 (on the "True Man") and finally to No. I4I, the "Analysis of Truths." In this sutta Buddha exhorts the disciples to obey Sariputto and Moggallano.

Besides these there are texts from the Classified and Numerical Collections, one of which is Buddha's First Sermon, also included by Rhys Davids in his volume of suttas aforesaid.

Besides the illustrious Parthian, many more translators of differnt nations went to China to continue the good work, and one of these, in the third century, translated the 9Ist sutta of the Majjhima, the Brahmayu, which gives the vivid account of Buddha's personal appearance, his table-manners, his gait, and daily habits, first made known by Spence Hardy in 1853. In Hardy's mediæval version, Buddha says grace, but this is not in the Pali. It would be inter- 
esting to know whether the third-century translator found it in the lost Hindu original before him.

In this interesting old sutta, we have a full-length life-picture of Gotamo of undoubted historical truth, and I often say that this discourse alone justifies the assertion that we know more about him than about Jesus.

Now, it has long been my contention that these Hinayana texts of the second and third centuries deserve special study. They are the first Buddhist sūtras of the primitive collections which we can date. The books translated into Chinese in the first three centuries were largely Mahayana and later on they were altogether so. Could not a little text-book be made of the Pali suttas translated by the Parthian, with, say, the third-century Brahmayu added? Give the original Pali, and note Chinese various readings, as Anesaki has done in my Buddhist and Christian Gospels.

This perhaps is the most crying need of Buddhist scholarship. Next to this, if not before it, I rank the translation of the Great Council Discipline (Maha-Sanghika-Vinaya). This sect was the sworn enemy of the school of the Elders who have transmitted to us the Pali. Each sect accused the other of falsifying the scriptures, so that any agreement between them would go back to an enormous antiquity. I do not myself believe that the final schism took place at Vesali, as the Ceylon Chronicles would have it, but at an obscure council held by Agnimitra, about the middle of the second century B. C. My reasons for this are the statements from the Great Council Discipline translated by Samuel Beal, in his learned Introduction to $S$. B. E., Vol. XIX; and, by the way, I was lately very much pleased to see his pioneer work highly commended by a distinguished French sinologue.

The Great Council Discipline was brought to China by Fa-Hien in A. D. 415, and some scholar who had overlooked the translators of the earlier centuries once asserted that this Discipline was the first Buddhist book we could date!

One of the most curious things in this Discipline is its list of the sacred books, and it was translated for us by Suzuki in The Monist for January, 1904. The present writer has taken occasion to draw conclusions from this in previous articles. (See, for example, the San Francisco Light of Dharma, January, 1905, and the fourth edition of Buddhist and Christian Gospels, Vol. I, pp. 82 and 266.)

There are reams upon reams of translation and critical work 
to be done, but, in my opinion, these two are the most elementary, most necessary and most immediately pressing. I appeal to the sinologues of France, Holland and Japan to emulate each other in this important task.

Albert J. Edmunds.

Historical Society of Pennsylvania, Nov. i6, igio.

\section{PROF. K. BORINSKI ON W. B. SMITH'S BIBLICAL CRITICISM.}

Prof. Karl Borinski has devoted to a discussion of Prof. W. B. Smith's theory of the pre-Christian Jesus an exhaustive article in a German periodical of Leipsic entitled Xenien. Extracts from the article were translated in The Monist (October, 1908). He recommends this most destructive and radical method as finally leading to new positive issues. He says:

"We look forward to the promised continuation of our author's researches in such a well-ransacked region, indeed, with intense expectation. In this remarkable investigator, with all his radicalism, there breathes no breath of destructive zeal, but rather, through and through, a constructive and requickening criticism.... Investigations like the foregoing furnish clear proof that there is no better antidote for the much decried 'destructive' tendencies of biblical criticism than its own self-than resolutely to follow out its most delicate and 'dangerous' researches and reasonings to the very end."

The "constructive and requickening" quality of this criticism is particularly conspicuous in the "promised continuation," shortly to appear in German under some such title as, "Ecce Deus, the Witness of the Gospels to the Pre-Christian Cult of the Jesus."

\section{GENERAL CONGRESS OF MONISTS.}

Those German Monists who have been associated together under the name of Monistenbund for more than four years, intend to convert their fifth annual meeting into a General Congress of Monists. It will convene at Hamburg, September 8-11, 1911. Professor Ernst Haeckel has consented to act as honorary president and the program contains very prominent names, including among its lecturers Professors Svante Arrhenius, of Stockholm ; Friedrich Jodl, of Vienna ; Jacques Loeb, of New York; and Wilhelm Ostwald of Leipsic, each of whom will speak on his own specialty. 